Vol. 8 No. 3, August 2014

Journal of EduLearn Eclucation and Learning

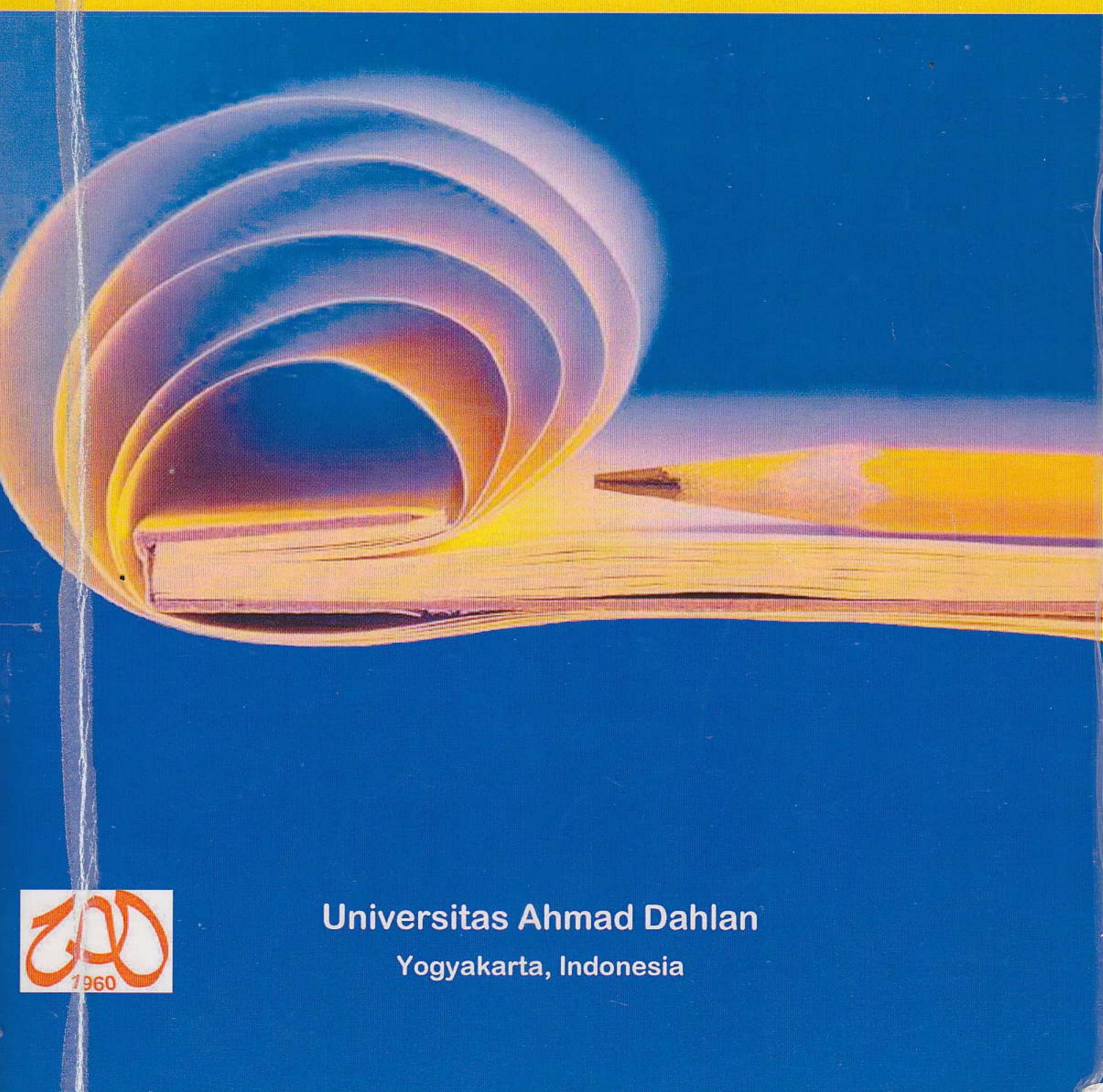




\section{Eeducation and Learning Edulearn}

The Effect of Electronic Portfolio Assessment Model to Increase of Students' Generic

Science Skills in Practical Inorganic Chemistry

Ramlawati, Liliasari Liliasari, Muhamad Abdulkadir Martoprawiro,

Ana Ratna Wulan

Compare Unidimensional \& Multidimensiona! Rasch Model for Test with Multidimensional

Construct and Items Local Dependence Ali Hasmy

Attitudes and Motivation toward Learning the English Language among Students from

Islamic Education System Background: Exploring the Views of Teachers Ismail Sheikh Ahmad, Hazlina Abduliah, Muhammad Faizal A Ghani

Limiting Skills Gap Effect on Future College Graduates James A. Ejiwale

The Relationship between Personal Mastery and Teachers' Competencies at Schools in Indonesia

Settaraming Algi, Mohd Anuar Abdul Rahman

Professional Learning Community in Secondary Schools Community in Malaysia

Zuraidah Abdullah, Muhammad Faizal A. Ghani

Interrogation in Teacher-Student Interaction in Bahasa Indonesia Learning at Elementary

School

Akmal Hamsa, Sultan

Grammar Consciousness-Raising Activities and Iranian EFL Learners' Attitudes toward English Language

Farrokhlagha Heidari, Nurullah Mansourzadeh

The Dynamics of Malay Culture in West Kalimantan in the 20th Century Ita Syamtasiyah Ahyat

The Development of Writing Learning Model Based on the Arces Motivation for Students of

Senior High School

Andreas Kosasih

The Journal of Education and Learning (EduLearn) is published by Universitas Ahmad Dahlan (UAD) in collaboration with Institute of Advanced Engineering and Science (IAES) Indonesia Section.

Responsibility of the contents rests upon the authors and not upon the publisher or editors.

\begin{tabular}{|c||c|c|c|c||c|}
\hline EduLearn & Vol. 8 & No.3 & pp. 179-290 & Yogyakarta, August 2014 & ISSN: 2089-9823 \\
\hline
\end{tabular}




\section{Edulearn Education and Learning}

Journal of Education and Learning (EduLearn) is an interdisciplinary international journal of original research and writing on education. The EduLearn aims to provide a forum for scholarly understanding of the field of education and plays an important role in promoting the process that accumulated knowledge, values, and skills are transmitted from one generation to another; and to make methods and contents of evaluation and research in education available to teachers, administrators and research workers.

\section{Editor-in-Chief:}

\section{Editorial Board Members}

Dwi Sulisworo, Universitas Ahmad Dahlan, Yogyakarta, Indonesia

\section{Co-Editor-in-Chief:}

Sagini Keengwe, University of North Dakota, United States

\section{Managing Editor:}

Lina Handayani, Universitas Ahmad Dahlan, Yogyakarta, Indonesia

\section{Editors:}

Alok K. Verma, Old Dominion University, United States

Dat Bao, Monash University, Australia

Effandi Zakaria, Universiti Kebangsaan Malaysia, Malaysia

Gianina-Ana Masari, Alexandru Ioan Cuza University, Romania

Giti Javidi, Virginia State University, United States

Jen-Chia Chang, National Taipei University of Technology, Taiwan

Kususanto Prihadi, Universiti Sains Malaysia, Malaysia

Ngurah Made Darma Putra, Universitas Negeri Semarang, Indonesia Ni Nyoman Padmadewi, Ganesh University of Education, Indonesia Rafael Denadai, Institute of Plastic and Craniofacial Surgery, Brazil Robert Bruce Kelsey, Thomas College, United States

Samir Kumar Lenka, Kalyani University, india

Tecnam Yoon, University of Massachusetts, United States

Tutut Herawan, Universiti Malaya, Malaysia

Wade Clay Smith, Walden University, United States

Waspodo Tjipto Subroto, University State of Surabaya, Indonesia

William Edward Roberts, New York City College of Technology, United States

\section{Advisory Director:}

Sarbiran, Universitas Ahmad Dahlan, Indonesia

Executive Director \& Chief Operating Officer:

Tole Sutikno, Universitas Ahmad Dahlan, Indonesia

Vice Executive Director and Treasurer:

Nur Fatimah, Universitas Ahmad Dahlan, Indonesia

Publications and Technical Activities:

Herlina Siwi Widiana, Universitas Ahmad Dahlan, Indonesia

Muhammad Joko Susilo, Universitas Ahmad Dahlan, Yogyakarta, Indonesia

Mustamin Mustamin, Universiti Teknologi Malaysia, Malaysia

Surono, Universitas Ahmad Dahlan, Indonesia

Syahruddin Lasadike, Dinas Pendidikan Kabupaten Barru, Indonesia

Proofreading Editors:

Ani Susanti, Universitas Ahmad Dahlan, Indonesia

Nur Fatimah, Universitas Ahmad Dahlan, Indonesia

Surono Surono, Universitas Ahmad Dahlan, Indonesia

Supporting Staffs:

Nooria Sukmaningtyas, Universitas Ahmad Dahlan, Yogyakarta, Indonesia

Tri Marjianto, IAES Indonesia Section, Yogyakarta, Indonesia

\section{Publisher}

\section{Universitas Ahmad Dahlan Yogyakarta, Indonesia}

Website: http://journal.uad.ac.id/index.php/EduLearn Email: edulearn@journal.uad.ac.id, info@journal.uad.ac.id 


\section{Table of Contents}

The Effect of Electronic Portfolio Assessment Model to Increase of Students' Generic Science Skills in Practical Inorganic Chemistry

Ramlawati, Liliasari Liliasari, Muhamad Abdulkadir Martoprawiro, Ana Ratna Wulan

Compare Unidimensional \& Multidimensional Rasch Model for Test with Multidimensional Construct and Items Local Dependence Ali Hasmy

Attitudes and Motivation toward Learning the English Language among Students from Islamic Education System Background: Exploring the Views of Teachers Ismail Sheikh Ahmad, Hazlina Abdullah, Muhammad Faizal A Ghani

Limiting Skills Gap Effect on Future College Graduates

James A. Ejiwale

The Relationship between Personal Mastery and Teachers' Competencies at Schools in Indonesia

Settaraming Algi, Mohd Anuar Abdul Rahman

Professional Learning Community in Secondary Schools Community in Malaysia Zuraidah Abdullah, Muhammad Faizal A. Ghani

Interrogation in Teacher-Student Interaction in Bahasa Indonesia Learning at Elementary School

Akmal Hamsa, Sultan

Grammar Consciousness-Raising Activities and Iranian EFL Learners' Attitudes toward English Language

Farrokhlagha Heidari, Nurullah Mansourzadeh

The Dynamics of Malay Culture in West Kalimantan in the 20th Century Ita Syamtasiyah Ahyat

The Development of Writing Learning Model Based on the Arces Motivation for Students of Senior High School 
Akmal Hamsa, Sultan. (2014). Interrogation in Teacher-Student Interaction In Bahasa Indonesia Learning at Elementary School. Journal of Education and Learning. Vol.8 (3) pp. 249-256.

\title{
Interrogation in Teacher-Student Interaction in Bahasa Indonesia Learning at Elementary School
}

\author{
Akmal Hamsa \\ Universitas Negeri Makassar \\ Sultan ${ }^{* *}$ \\ Universitas Negeri Makassar
}

\begin{abstract}
Interrogation in Teacher-Student Interaction in Bahasa Indonesia Learning at Elementary School. This study aimed to describe the form, function, and questioning strategies teachers in teacher-student interrogation in Bahasa Indonesia learning in elementary school. Data sourced from four teacher of elementary school, SDN Tamangapa and SD Inpres Tamangapa. Data were obtained by (1) recording, (2) documentation, (3) field notes, (4) interview. The results showed that: (1) the form of questioning the teacher in the teacher-student interaction in Bahasa Indonesia learning in primary schools generally examined the low-level thinking skills, (2) functions of teacher questions are generally intended to check student understanding, and (3) teachers utilize a variety of strategies in addressing student answers correctly and the apparent hesitation. Some disadvantages are indicated teachers in providing interrogation.
\end{abstract}

Keywords: interaction of learning, interrogation, the teacher's questioning

\footnotetext{
Akmal Hamsa, Fakultas Bahasa dan Sastra Universitas Negeri Makassar Jalan Mallengkeri, Kampus Parangtambung UNM, Makassar

E-mail: akmalhamsa.unm@gmail.com

** Sultan, Fakultas Bahasa dan Sastra Universitas Negeri Makassar Jalan Mallengkeri, Kampus Parangtambung UNM, Makassar
} 


\section{Introduction}

A good communication between teachers and students is one of the determinants of successful learning. By using interactive communication, teachers and students can interact and exchange information to achieve learning objectives. Conversely, a poor communication between the two parties can lead to failure of learning.

Interrogation is one of the medium used to communicate with each other in the learning interaction. Interrogation by using the right questions can improve the quality of teacher-student interaction. The results Widodo (2006a) concluded that the impetus provided by the teacher to the students to ask questions can improve the quality and quantity of students' question. These questions arise in the interaction with interrogation learning between teachers and students, students and students, or students with others that were presented as a learning resource.

A number of studies conducted by Rosenshine and Furst were quoted as saying by Muijs and Reynolds (2008:66) showed that the use of variety of questions is an important factor in learning. Research conducted in the span of time shows that through the questions, teachers can create interactive learning.

Contextual approach that characterizes the world of education today asked placing elements (questioning) as one of the main components in the learning. According Nurhadi (2003: 46), this activity is useful to explore the information asked, checking understanding, solve problems, generate responses, fulfill curiosities, check out what is already known, focus attention, provoke further questions, and refresh students' knowledge.

The use of questions in learning activities can improve self-esteem (Muijs and Reynolds, 2008:67). According Muijs and Reynolds, students are able to answer questions properly would generate confidence. Students are able to master and understand learning. The resulting effect is a more motivated student learning, including learning to follow next.

Many benefits can be obtained through the questionnaire showed that the questioning is an essential component in learning. However, the use of questions requiring skill and strategy of the teacher can create interactive classroom. Teachers are required to have adequate skills interrogate, interrogate and momentum strategies such as the right to ask questions.

The results Widodo (2009) demonstrated that the ability of prospective students of primary school teachers in asking productive questions still relatively low. Through these studies, it was found that most students have not been able to ask the question well. This is a problem because of the use of productive questions needed to maximize learning outcomes. In addition, elementary school teachers are required to be able to facilitate learning through inquiry.

Teacher competence in selecting, using, and asking the questions is critical achievement of learning objectives. The results Nalole (2010) on teachers' questioning skills in learnilig in primary schools showed that in conducting interrogations, the teacher guiding the student has not been done, no tracking, and the question has not spread. From these studies, it appears that teachers have used question in learning interactions, but how to ask questions and form teacher still has a number of disadvantages.

In addition to teachers, students are also required to ask a question in learning interactions. The questions raised by students can be used to enhance understanding of the material. For teachers, student questions can be used as a measure of students' understanding of the material or activity is presented. However, in asking students also sometimes has a number of constraints. Widodo (2009: 6) found that feelings of doubt, shame, and fear of a problem student to ask questions.

In learning Indonesian, it is emphasis on developing communication skills of students. Skills to communicate effectively and efficiently can be started from an interactive classroom interaction through the use of questions. The questions that the teacher makes in the interaction in order to increase the effectiveness of teaching and learning outcomes and encourage student communication skills. These objectives can be achieved through the precision of the teacher in conducting interrogations, questioning strategies, and types of questions asked.

Research on the analysis of the questionnaire was done by Maryati (2008) which examines the use of questions in the Student Worksheet (LKS) in secondary schools in teaching Biology and Tika (2011) which examines the question of laboratory operations. In contrast to the two studies that take a background in high school, the study was conducted at the primary school level and on different subjects.

This study aims to analyze the models proposed interrogation of teachers in the learning interaction Indonesian at primary school. This research was conducted to map the skills to interrogate and classify the type of questions asked of teachers. The results can be used as the basis for the development of teachers' pedagogic competence. 


\section{METHOD}

This study includes the type of qualitative research. The study was conducted to provide a detailed description of the symptom or phenomenon under study. The data in this study is forms, strategies, and functions of questions that used by teachers and students in the learning interaction. The data is in the form of oral and written in learning interactions.

The main data source of this research is the speech teacher and student learning in interaction. Supporting data sources are written documents that empowered teachers in the learning process. Data sourced from the interaction of speech teachers teaching four classes V and VI Tamangapa presidential primary and SDN Tamangapa, District Mangala, Makassar.

Data collection conducted by (1) recording, (2) documentation, (3) field notes, (4) interview. The data was collected through tools such recording handy cam Sony DCR-HC85E.

Checking the validity of data is done through (1) persistence of observations, (2) extension of the observation, (3) the examination and discussion of peers, and (4) triangulation (Alwasilah, 2003: 151; Moleong, 1990: 175-183, and Iskandar, 2008: 229-232).

Data analysis was conducted by Miles and Huberman Flow Model consists of: (1) data reduction, (2) the presentation of data, (3) drawing conclusions and verification (Miles \& Huberman, 1992). Stage of data reduction is done by eliminating irrelevant data and selecting the required data. The results of field data were selected and grouped according to the focus of the research problem.

Stage presentation done in a matrix of categories embodied in the form of descriptions and tables. Data are presented with a simple statistical analysis of the percentage of the fitted shape with a narrative to provide a comprehensive explanation.

\section{Being Interrogation Teachers}

Interrogation Classification Based on Knowledge Dimension Bloom

Bloom's taxonomy of learning objectives that have been revised Anderson and Krathwohl (Anderson and Krathwohl, 2010) is divided into two, namely the dimensions of knowledge and cognitive process dimensions. Dimensions of knowledge are divided into four categories, namely factual knowledge, conceptual knowledge, procedural knowledge and metacognitive knowledge. Being interrogated by the dimensions of teacher knowledge of Bloom are shown in Table 1 below.

Table 1. Teacher Interview Form Based Dimension Knowledge of Bloom

\begin{tabular}{ccc}
\hline Knowledge Dimension & Frequency & Percent \\
\hline Factual & 75 & 77.32 \\
Conceptual & 20 & 20.62 \\
Procedural & 2 & 2.06 \\
Metacognitive & 0 & 0.00 \\
\hline
\end{tabular}

Based on Table 1, it appears that the teacher asked three of the four dimensions of knowledge Bloom. Teachers do not provide for the interrogation of metacognitive knowledge. Factual knowledge is knowledge that most high-dimensional intensity interrogation realized teacher. Once the factual knowledge, other interrogation types are realized teachers are conceptual and procedural knowledge. However, these two dimensions of knowledge have a much smaller light intensity compared with the factual knowledge. She even tidan give any interrogation for metacognitive knowledge dimension.

Interrogation Classification Based on Bloom's Cognitive Dimension Process

Bloom's cognitive process dimension is divided into six levels, namely remembering, understanding, applying, analyzing, evaluating, and creating. Data from teacher questioning by Bloom cognitive process dimensions are shown in Table 2 below.

Table 2. Teacher Interview Form Based Bloom's Dimension Cognitive Process

\begin{tabular}{ccc}
\hline Cognitive Process & Frequency & Percent \\
\hline Giving & 77 & 79.38 \\
Understanding & 13 & 13.40 \\
Applying & 2 & 2.06 \\
Analyzing & 5 & 5.15 \\
Evaluating & 0 & 0.00 \\
Creating & 0 & 0.00 \\
\hline
\end{tabular}


Based on Table 2, it appears that the teacher gave interrogation on four of the six dimensions of cognitive processes Bloom. Teachers provide the highest interrogation cognitive processes given, followed by cognitive processes to understand, analyze, and apply. Teachers do not give interrogation on cognitive processes to evaluate and create. Teachers' questioning is dominant low-level cognitive processes (low-order of thinking). Instead, it is limited to providing interrogation of high-level cognitive processes (high order of thinking).

Broad-Based Classification narrowness Interrogation Target

Based on wide-narrow objectives, questions are classified into two types, namely the closed questions and open questions. Closed questions are questions that refer to the category of a single answer (convergent). Open-ended questions are questions that enable the emergence of classification varied answers. Being interrogated by extensive teacher-narrow target is shown in Table 3 below.

Table 3. Form Teachers under Interrogation The narrowness of the broad-Target

\begin{tabular}{ccc}
\hline The narrowness of the Target Area Classification & Frequency & Percent \\
\hline Closed questions & 82 & 84.54 \\
Open Question & 15 & 15.46 \\
\hline
\end{tabular}

Based on Table 3, it appears that the teachers are very dominant in providing interrogation through a closed question. A total of 84.54 percent of closed questions are given, the remaining 15.46 percent is an open question. Through Table 4.3 it can be concluded that the questions asked of teachers generally require a uniform answer.

\section{Products or Question Classification Process Interrogation}

Based on the nature of the response, the interrogation can realize through the process of product questions and inquiries. Answer questions raised products that are sure to involve low-level thought processes, whereas the question requires generic skills, such as problem-solving skills by involving higher-order thinking skills. Being interrogated by teachers or product inquiry process questions is shown in Table 4 below.

Table 4. Form Product or Process Interrogation

\begin{tabular}{ccc}
\hline Classification Interrogation & Frequency & Percentage \\
\hline Products & 81 & 83.51 \\
Process & 16 & 16.49 \\
\hline
\end{tabular}

Based on Table 4, it appears that the teachers are very dominant in providing interrogation through product questions. A total of 83.51 percent of a given product questions, process questions remaining 16.49 percent. Through Table 4.4 it can be concluded that the questions asked of teachers generally involve only low-level thought processes of students.

Interrogation Under That Classification

Based on the intention, interrogation teachers can be classified into: a question request, rhetorical questions, direct questions, and explore the question. Being interrogated by means teachers are shown in Table 5 below.

Table 5. Form Teacher under Interrogation point

\begin{tabular}{ccc}
\hline The purpose Interrogation & Frequency & Percentage \\
\hline Demand & 17 & 17.53 \\
Rhetorically & 21 & 21.65 \\
Directing & 38 & 39.18 \\
Digging & 21 & 21.65 \\
\hline
\end{tabular}

Based on Table 5, it appears that teachers conduct interrogations with the intention of digging student understanding. Question digging is a form of questions put to enhance student understanding by providing follow-up questions. Rhetorical questions and direct questions ranked second. Based on the intention, the most lacking is the question demands. The types of questions asked students aiming requests to perform certain activities. 


\section{Interrogation Function Teachers}

Interrogation of teachers to students has a variety of functions. Interrogations were submitted by teachers serves to clarify the processes, procedures, and learning materials. Based on the impact, the teacher interrogation functions are categorized into: direct understanding, learning readiness checks, increase participation, focus, comprehension checks, and to lead the process of thinking. The function of the teacher interrogation is shown in Table 6 below.

Table 6. Function Interrogation Teacher Learning in Interaction

\begin{tabular}{ccc}
\hline Cognitive Process & Frequency & Percentage \\
\hline Directing understanding & 11 & 11.34 \\
Checking readiness to learn & 15 & 15.46 \\
Increasing the participation of & 10 & 10.31 \\
Focusing & 10 & 10.31 \\
Check for understanding & 44 & 45.36 \\
Guide the process of thinking & 7 & 7.22 \\
\hline
\end{tabular}

Based on Table 6, it appears that teachers utilize questioning to various functions in the interaction of learning Indonesian in elementary school. Checking function of understanding has the highest usage frequency. The function of directing, checking readiness to learn, increase participation, and focusing used equally. Interrogation function guides the thinking process of students is the lowest function utilized teacher.

\section{Interrogation Strategy of Teacher}

Teacher questioning strategies in learning Indonesian in primary school consists of two categories, namely teacher strategies in dealing with the correct answers and strategies for teachers to handle the answer is wrong. In addition, this study also found a false teacher questioning strategies.

The strategies used by teachers in dealing with the correct answer in the teacher-student interaction in primary schools comprising: granting any further queries, reinforcement, repeat the correct answer, and review student answers. Teachers utilized strategies to deal with students who are less correct answer consists of two, namely: providing guidance (prompting) and feedback. Strategies teachers are wrong/less precise in providing interrogation, including: answering his own question, formulation, and asked the name of the student, not direct disciple erroneous response, and scold students who give false responses.

\section{DISCUSSION}

The results showed that the dominant dimension of factual knowledge $(77.32 \%)$ asked teachers in teacher-student interaction in learning Indonesian Language in Elementary School. Dominant question examined the factual knowledge indicates that the teacher directs students just remember facts. In fact, the only factual knowledge is the basic elements that must be learned by the students to solve problems in the areas studied (Anderson and Krathwohl, 2010). Starting from the view of Anderson and Krathwohl, an ideal learning does not just stop on the ability to remember and find the facts, but the

- factual knowledge should be the basis in developing the dimensions of knowledge, namely knowledge of conceptual, procedural, and metacognitive. Low-level questions should only be used as a basis for developing high-level questions, improve attention, or foster student enjoyment.

From the dimensions of cognitive processes, the results showed that the teachers really prioritize providing questions that are at the level of recall $(79.38 \%)$. Cognitive processes to remember, understand, and apply the dimensions grouped in low-level cognitive processes (low order of thinking). The questions asked of teachers in all three cognitive processes such as accumulation reaches $94.85 \%$. Thus, learning Indonesian in primary schools can be summed up more to dwell on the fact that developing low-level thought processes. Only $5.15 \%$ questions were developed to analyze cognitive processes. Not one $(0.00 \%)$ questions the teacher to evaluate the level and create.

The dominance of teacher questions that are at the level of low-level cognitive processes may have implications for students in the long run. These questions are less developed reasoning power and students' thinking processes. In effect, students will lose the power of creativity and the power of reason in the face of problems involving the process of analyzing, evaluating, or creating (high order of thinking). Learning practices that emphasize mastery of facts involving thought process is a low-level instructional practice that has taken place in the past. Two international assessments on students' learning achievement in Indonesia, the Progress in International Reading Literacy Study (2012) and the 
Programme for International Student Assessment (2010) which showed that the average score of the acquisition of Indonesian students are below the average OECD country (Organization for Economic Development). At the second assessment, the difficulty of solving the problem that involves the ability to analyze, evaluate, and create (high order of thinking).

From the wide-narrow objectives, questions asked teachers predominantly closed questions. Closed questions require a single response from the students, as opposed to open-ended questions that provide an opportunity for students to think Multi-perspective. According Widodo (2006b) dominance of the teacher asking questions that require short answers, for sure, and is rote indicate that the ability to ask the teacher needs to be improved. Teachers should be trained to develop questions that develop students' analytical and reasoning power in the form of open-ended questions. Open-ended questions provide possible answers are so diverse that encourages creative thinking of students.

The dominance of closed questions lead students does not have the freedom to express ideas and thoughts creatively. This is in line with the opinion Muijs and Reynolds (2008) argued that learning a predominantly closed question about the cognitive challenges to students. In other words, the effectiveness of teachers are teacher who design and deliver a lot more open-ended questions to students.

Based on the nature of the answers, the questions asked teachers questions categorized into product and process questions. Answer product questions arose in the form of factual knowledge and its certainty, while the question raises a variety of responses by first requires students to use the thinking process. The results showed that the dominant product questions the teacher than the question. Dominant product questions cause students not to use cognitive science to learn to solve problems (problem solving). Learning that directs students to solve problems require more complex thinking level by combining some thinking skills, such as analysis and evaluation. Muijs and Reynolds (2008) suggested that effective teachers use more questions than the questions the product.

Based on the intent of questions asked, the questions posed questions aimed predominantly teacher directed. Instead, the question aims to explore students' understanding is more limited. This is due to goal-oriented teacher asked a question on extracting facts or knowledge. Teacher directs students to find specific information, not developing thought processes. Finally, in the process of learning the questions posed teacher directs students to give definite information that has been thought out by the teacher.

Based on the five classification models questions that have been described, it can be concluded that teachers' questioning skills in teacher-student interaction in learning Indonesian in primary schools is low. Questions raised more leads students to use low-level thought processes. In addition, the number of questions in the learning activities is also relatively low.

From the observations and interviews, it is known that the plan question the ability of teachers to provide due to the following. First, teachers do not regard the use of questions as good learning techniques to increase student participation. Second, teachers develop more oriented learning with students master the learning materials than developing reasoning power and the capacity to think. Third, by making teachers teaching textbooks as the main source of learning, filled with learning more about the exercises that exist in the text book. The order of learning is done in accordance with textbooks. Fourth, teachers do not have teaching preparation in the form of an implementation plan that accommodates the provision of learning the questions to the students. Fifth, teacher-developed learning strategies more dominated assignment. The main learning activity is to discuss homework and work on the problems in textbooks and then continued the discussion.

Interrogation teachers have diverse functions, which directs the understanding, learning readiness checks, increase participation, focus, comprehension checks, and to iead the process of thinking. Check function is a function of understanding the most dominant teachers. This happens because the questions asked teachers more oriented to test student understanding. Given question aims to measure the ability of students to understand the concepts or facts presented teachers.

Teachers use a variety of strategies in asking questions, both in dealing with the correct answer as well as in dealing with students who hesitate. In dealing with the correct answer, the teacher uses advanced queries, reinforcement, repeat the correct answer, and review student answers. In dealing with the wrong answer, the teacher uses prompting, feedback. The use of both strategies indicates that teachers have adequate questioning skills.

Some disadvantages teachers in providing the questions found, namely answer his own question without adequate wait time, using the formulation, and asked the name of the student, not directing student gives a wrong response, and the disciples rebuked the wrong response. This weakness is the pedagogical aspects that must obtain development. 


\section{CONCLUSION}

Shape interrogation teachers in teacher-student interaction in learning Indonesian in primary schools generally examined the low-level thinking skills. Teacher questions of factual knowledge/products are dominated. Teachers are lacking in providing questions that involving the high level thinking skills of students. The function of the teacher questions aimed at checking students' understanding. This happens because the questions asked teachers more oriented to test student understanding. Given question aims to measure the ability of students to understand ti:e concepts or facts presented teachers.

Teachers utilize a variety of strategies to address the student answers correctly and the apparent hesitation. Some disadvantages teachers in providing the questions found, namely answer his own question without adequate wait time, using the formulation, and asked the name of the student, not directing student gives a wrong response, and the disciples rebuked the wrong response.

\section{References}

Alwasilah, A. Chaedar. 2003. Pokoknya Kualitatif: Dasar-dasar Merancang dan Melakukan Penelitian Kualitatif. Jakarta: Pustaka Jaya.

Anderson, Lorin W. dan Krathwohl. 2001. A Taxonomy for Learning, Teaching, and Assesing; A Revision of Bloom Taxonomy of Education Objecties, A Bridgel Edition. Diterjemahkan oleh Agung Prihantoro. 2010. Yogyakarta: Pustaka Pelajar.

Iskandar. 2008. Metodelogi Penelitian Pendidika dan Sosial. Jakarta: GP Press.

Maryati, Yati. 2008. "Analisis Pertanyaan yang Dikembangkan dalam Lembar Kerja Siswa". UPI Bandung (Online): http://repository.upi.edu.

Miles, Matthew B dan A. Michael Huberman. Tanpa Tahun. Analisis Data Kualitatif. Terjemahan oleh Tjejep Rohendi Rohidi. Jakarta: UI Press.

Moleong, Lexy J. 1990. Metodologi Penelitian Kualitatif. Bandung: Remaja Rosda-karya.

Muijs, Daniel dan David Reynolds. 2008. Effective Teaching. Diterjemahkan oleh Helly Prajitno Soetjipto dan Sri Mulyantini Soetjipto. 2008. Yogykarta: Pustaka Pelajara.

Nalole, Martianty. 2010. "Kemampuan Guru Menerapkan Keterampilan Bertanya pada Pembelajaran Matematika di Kelas IV SD Negeri No. 64 Kota Timur Kota Gorontalo", Jurnal Inovasi, VII(2): $814-824$.

Nurhadi, Burhanuddin Yasin, dan Agus G.S. 2003. Pembelajaran Kontekstual dan Penerapannya dalam KBK. Malang: UM Press.

PIRLS. 2012. PIRLS 2011 Result International in Reading. Boston USA: TIMSS and PIRLS International Study Center.

PISA. 2010. "PISA 2009 Executive Summary". Tanpa Lokasi. OECD.

Widodo, Ari. 2006a. "Peningkatan Kemampuan Siswa SD untuk Mengajukan Pertanyaan Produktif", Jurnal Pendidikan dan Pembelajaran, 4(1), 1-12.

Widodo, Ari. 2006b. "Profil Pertanyaan Guru dan Siswa dalam Pembelajaran Sains", Jurnal Pendidikan dan Pembelajaran, 4(2): 139-148.

Widodo, Ari. 2009. "Peningkatan Kemampuan Mahasiswa PGSD dalam Mengajukan Pertanyaan Produktif untuk Mendukung Pembelajaran IPA Berbasis Inkuiri", Jumal Pendidikan, 10(1): 21-29. 